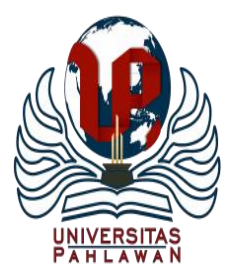

Edukatif : Jurnal Ilmu Pendidikan Volume 3 Nomor 1 Tahun 2021 Halm 8 - 13 EDUKATIF: JURNAL ILMU PENDIDIKAN

Research \& Learning in Education

https://edukatif.org/index.php/edukatif/index

\title{
Teori Belajar Bahasa
}

Sri Hastuti ${ }^{1 凶}$, Neviyarni $^{2}$

Universitas Negeri Padang, Indonesia ${ }^{1,2}$

E-mail : shastuti732@ gmail.,com ${ }^{1} \underline{\text { neviyarni.suhaili911@ @mail.com }}^{2}$

\begin{abstract}
Abstrak
Artikel ini membahas tentang teori belajar bahasa menggunakan rujukan dari kajian literatur yang relevan, dalam konsepnya bahasa merupakan alat dasar yang digunakan manusia untuk berpikir. Karateristik bahasa terdiri dari fungsi bahasa, unit dasar bahasa:fonem dan morfem, level tertinggi dari analisis bahasa, struktur frase dalam kalimat, struktur permukaan dan struktur dalam. Adapun isu-isu dalam bahasa yaitu, perkembangan bahasa, bahasa dan proses berpikir, bahsa pada hewan, perbedaan budaya dalam bahasa, berbicara dan otak manusia. Adapun teori-teori belaar bahasa yaitu, pendekatan pengkondisian, dan pendekatan psikolinguistik.
\end{abstract}

Kata kunci: belajar bahasa

\begin{abstract}
This article discusses the theory of language learning using references from relevant literature studies, in the concept that language is a basic tool used by humans to think. The characteristics of language consist of language functions, the basic units of language: phonemes and morphemes, the highest level of language analysis, the structure of phrases in sentences, surface structures and inner structures. As for the issues in language, namely, the development of language, language and thought processes, language in animals, cultural differences in language, speech and the human brain. As for the theories of language defense, namely the conditioning approach and the psycholinguistic approach.
\end{abstract}

Keywords: learn a language

Copyright (c) 2021 Sri Hastuti, Neviyarni

$\triangle$ Corresponding author

Email : shastuti732@gmail.com

DOI: https://doi.org/10.31004/edukatif.v3i1.179

ISSN 2656-8063 (Media Cetak)

ISSN 2656-8071 (Media Online) 


\section{PENDAHULUAN}

Bahasa adalah kemampuan individu dalam menyampaikan sesuatu yang dimana tujuannya memberitahu informasi. Bahasa adalah sebuah sistem bunyi yang arbriter, konvensional, yang dapat digunakan untuk berkomunikasi (Harras \& Bachari, 2009). Proses meraih bahasa memberikan sesuatu tentang perkembangan salah satu fungsi terpenting pada manusia dan kajian terhadapnya merupakan topik psikolinguistik (Jumhana, 2014).

Bahasa yang jelas dapat menciptakan keadaan efektif untuk menjalin komunikasi sosial. Informasi yang ingin disampaikan akan mudah dipahami jika disampaikan dengan bahasa yang baik. Tanpa bahasa, komunikasi tidak dapat dilakukan dengan baik dan interaksi sosial pun tidak akan pernah terjadi. Karena tanpa bahasa, siapa pun tidak akan dapat mengekspresikan diri untuk menyampaikan kepada orang lain. Oleh karena itu, bahasa adalah alat ekspresi bagi manusia. Melalui bahasalah manusia dapat mengorganisasikan bentukbentuk ekspresinya dalam kehidupan sosial di masyarakat. Bahasa merupakan salah satu aspek penting yang perlu diajarkan kepada para siswa di sekolah. Dari situ diharapkan siswa mampu menguasai, memahami dan dapat mengimplementasikan keterampilan berbahasa. Pembelajaran bahasa diarahkan untuk meningkatkan kemampuan siswa dalam berkomunikasi. Komunikasi tersebut tentunya dengan bahasa yang baik dan benar. Agar dapat berkomunikasi dengan baik, seseorang perlu belajar bahasa yang baik dan benar. Cara tersebut akan lebih baik jika diajarkan sejak dini dan berkesinambungan.

Selanjutnya pemerolehan bahasa merupakan proses yang dialami manusia dalam perkembangan bahasa yang bersifat alami. Bahasa dibentuk dari berbagai kombinasi kata yang mengacu pada aturan tertentu. Bagian yang paling dasar dari bahasa adalah fonem, yaitu bunyi yang dihasilkan oleh alat ucap manusia yang signifikan dalam membedakan makna (bunyi bahasa). Oleh karna itu belajar bahasa sangat diperlukan bagi setiap individu untuk mengembangkan potensi diri dan memperoleh pengetahuan mengenai apa yang dipelajari. Bahasa mencakup segala bentuk komunikasi, baik yang diutarakan dalam bentuk lisan, tulisan, bahasa isyarat, bahasa gerak tubuh, ekspresi wajah pantomim atau seni.

Sebagai garis besar, perbincangan teori psikolinguistik tidak bisa terlepas dari memahami bagaimana manusia memahami bahasa, seperti apa cara memperoleh bahasa dan bagaimana tahap perkembangan bahasa dilalui sejak masa anak-anak (Indah, 2017a). Setelah bahasa dipahami, bagaimana manusia memproduksi bahasanya dan kendala apa saja yang dihadapinya. Jika bahasa mengalami perkembangan tentunya pengguna bahasa bisa menemui kesulitan pengembangan dan bahkan hilangnya kemampuan bahasanya (Indah, 2008).

Pemahaman bahasa merupakan bagian dari proses bahasa yaitu alat-alat, materi dan prosedur yang terdapat dalam mental manusia yang digunakan untuk memahai bahasa lalu kemudian untuk memproduksi bahasa. Jadi hal ini sangat berkaitan dengan persepsi manusia terhadap bahasa. Adapun yang dimaksud dengan persepsi bahasa adalah kemampuan manusia untuk menganalisis bunyi ujaran dan mengidentifikasikannya sebagai suatu kata atau kalimat, serta menangkap ide-ide yang terkandung dalam kalimat tersebut (Indah \& Abdurrohman, 2008).

Dalam kehidupan sehari-hari manusia tidak terlepas dari pemakaian bahasa. Dengan bahasa seseorang dapat mengungkapkan ide, gagasan, pikiran dan keinginan dalam menyampaikan informasi. Dalam mengungkapkan bahasa, manusia menggunakan berbagai macam ragam dan variasi yang disesuaikan dengan situasi di mana pembicaraan itu dilakukan. Bahasa yang dipakai untuk berbicara dengan orang tua, anak-anak, teman sejawat, pemimpin sekolah sangat berbeda. Kita pun akan menggunakan bahasa dengan cara yang berbeda apabila kita bertemu dengan teman pada keadaan yang berbeda pula. Dalam kaitan dengan hal itu, 
bahwa bahasa mempunyai keragaman jenis dan bervariasi karena bahasa dipakai oleh kelompok atau individu yang berbeda sifatnya. Oleh karna itu artikel ini membahas bagaimana karakteristik bahasa, Isu-isu dalam bahasa dan teori-teori belajar bahasa.

\section{METODE PENELITIAN}

Artikel ini membahas tentang teori belajar bahasa, jenis metode penelitian ini adalah analisis kajian pustaka (literatur research) artikel ini akan memaparkan analisis jurnal ilmiah yang relevan dengan pembahasan yang sudah dipilih, adapun tahap- tahap dalam metode penelitian ini adalah (1) memilih artikel, (2) mengumpulkan data awal, (3) tantangan dari topik, (4) mengumpulkan data pendukung, (5) menghasilkan kesimpulan dan rekomendasi online.

\section{HASIL DAN PEMBAHASAN PENELITIAN}

\section{A. Karakteristik Bahasa}

Bahasa adalah alat dasar yang digunakan manusia untuk berpikir. Bahasa dibentuk dari berbagai kombinasi kata yang mengacu pada aturan tertentu. Kata sendiri merupakan representasi dari simbolsimbol yang terbentuk dari huruf vokal dan konsonan. Bagian yang paling dasar dari bahasa adalah fonem, yaitu signifikan dalam membedakan makna (bunyi bahasa). Adapun karakteristik bahasa, yaitu: (Ellis, 1987)

a) Fungsi bahasa

1) Bahasa dapat menjadi alat dalam arti bahwa perilaku verbal dapat mengarah langsung pada penghargaan

2) Bahasa berfungsi sebagai rangsangan atau sinyal untuk perilaku lain

3) Bahasa berfungsi sebagai sarana

4) Bahasa menyampaikan makna

b) Unit dasar bahasa

Semua bahasa terbuat dari bunyi dasar yang disebut fonem. Bagi sebagian orang Amerika untuk mempelajari bahasa asing adalah karena fonem yang berbeda digunakan. Unit bahasa yang lain adalah morfem, yaitu unit terkecil dalam bahasa yang memiliki makna. Biasanya morfem terdiri dari kombinasi satu atau dua fonem yang kira-kira terbentuk pada kata-kata dasar. Kata kata good, put, dan go merupakan single morfem. Sedangkan kata goodness, putting, dan going terdiri dari dua morfem.Berdasarkan paparan diatas fonem adalah bahasa yang dari bunyi, sedangkan morfem adalah yang memiliki makna.

c) Level Tertinggi dari Analisis Bahasa

Berbagai investigasi di bidang psikologi mengambil bahasa sebagai salah satu unit dasar dari analisis. Terdapat beberapa tingkatan/level dimana analisis dapat dilakukan, diantaranya adalah:

1) Lexical content

Dalam penggunaan lexical content, analisis berkisar antara kata apa yang tepat digunakan. Lexical juga berkaitan dengan perbedaan kata-kata dalam bahasa yang paling sering digunakan.

2) Syntatic content

Penggunaan syntatic content berkenaan dengan bagaimana menyusun atau aransemen kata-kata menjadi sebuah kalimat. Dalam penyusunannya tersebut terdapat aturan-aturan sehingga muncul 
bagaimana bentuk kalimat yang benar dan tidak benar. Berbagai bentuk aturan yang memungkinkan pembentukan kalimat tersebut merupakan grammar.

\section{3) Semantic content}

Pembahasan dan analisis berkenaan dengan semantic content adalah mengenai makna dan pesan yang dibawa. Selain itu, juga mengandung analisis mengenai apa makna dari suatu kalimat.

d) Struktur frase dalam kalimat

Ahli bahasa merasa lebih berguna untuk mendeskripsikan kalimat dalam rangkaian frasa, yang merupakan kumpulan kata. Analisis ke dalam berbagai frase menggambarkan struktur frase dari sebuah kalimat.

e) Struktur permukaan dan struktur dalam

Para ahli bahasa membagi struktur kalimat menjadi dua, yaitu:

1) Surface structure (struktur luar) merupakan kalimat aktual yang memperlihatkan hubungan sederhana dari bagian-bagian dalam suatu kalimat.

2) Deep structure (struktur dalam) merupakan makna dari suatu kalimat, dimana terdapat spesifikasi dari hubungan yang logis dalam suatu kalimat.

Berdasarkan paparan diatas karakteristik bahasa yaitu fungsi bahasa, unit dasar, level tertinggi dari analisis bahasa, struktur frase dalam kalimat, struktur permukaan dan struktur dalam. Selanjutnya karakteristik bahasa adalah:
a) Bahasa Bersifat Abritrer
b) Bahasa Bersifat Produktif
c) Bahasa Bersifat Dinamis
d) Bahasa Bersifat Beragam

\section{B. Isu-isu dalam Bahasa}

Isu-isu yang terdapat dalam bahasa, yaitu: (Ellis, 1987)

a) Perkembangan Bahasa

Perkembangan bahasa mengikuti kursus yang cukup teratur. Permulaan bahasa dibuktikan dengan mengoceh, yang merupakan jenis vokalisasi dasar. Antara enam dan sembilan bulan, bayi mampu menghasilkan semua suara pidato dasar yang membentuk suatu bahasa. Proses perkembangan bahasa ini dapat ditingkatkan dengan bantuan dari orang dewasa, misalnya orang tua. Proses tersebut dapat berupa pengulangan bunyi yang dikeluarkan bayi, yang dinamakan dengan echoic responses. Perkembangan bahasa lebih mengarah kepada proses pematangan seperti halnya proses belajar.

Bunyi-bunyian yang dihasilkan bayi tersebut merupakan langkah awal dari proses berbahasa. Karena bunyi-bunyian harus dapat mewakili suatu simbol, objek dan situasi pada lingkungan anak tersebut. Sehingga, seorang anak harus belajar bagaimana mengasosiasikan simbol-simbol bunyi dengan aspek-aspek yang ada dalam lingkungan. Perkembangan bahasa pada anak juga menuntut mereka memiliki kemampuan menguasai bahasa secara cepat, hal ini dapat dipermudah dengan adanya interaksi sosial.

b) Bahasa dan Proses Berpikir

Bahasa dan proses berfikir memiliki hubungan yang saling keterkaitan. Kemampuan anak dalam memahami konsep berhubungan dengan perkembangan bahasanya. Tentu saja seorang anak yang 
mampu memverbalkan suatu hubungan misalnya "besar dari" "lebih baik dari" akan lebih baik dalam pemecahan masalah dibandingkan anak yang tidak mampu memverbalkan hubungan. Vgotsky berpendapat bahwa adanya satu tahap perkembangan bahasa adalah sebelum adanya pikiran dan adanya satu tahap perkembangan pikiran adalah sebelum adanya bahasa (Hidayat, 2014).

Namun demikian, bahasa tidak termasuk bagian yang begitu penting dalam proses mental yang kompleks meskipun bahasa merupakan bagian dari fasilitas pemecahan masalah. Hal ini berarti anak yang memiliki gangguan dalam berbahasa masih bisa memahami berbagai konsep. Bahasa juga tidak dijadikan bahan yang begitu penting dan esensial dalam perkembangan kapasitas kognitif seorang anak.

c) Bahasa pada Hewan

Binatang mempunyai bahasa tersendiri untuk berkomunikasi, namun binatang tidak mampu memproduksi kalimat dan tidak mampu menggunakan bahasa secara kreatif seperti manusia, dikarenakan binatang mempunyai kekurangan sistem alat ucap dan tidak memiliki aspek bahasa seperti manusia. Binatang berkomunikasi dengan anaknya hanya menggunakan isyarat saja, seperti : melalui suaranya. Bahasa binatang berbeda dengan manusia. Perbedaan itu disebabkan dalam bahasa manusia disadari ada "kesadaran nama" yaitu bahwa setiap bunyi-bunyi akan selalu menunjuk pada satu objek tertentu, peristiwa, orang benda atau presentasi lainnya (Muhibbin Syah, 2010).Berbagai riset dan penelitian telah dilakukan untuk melihat bagaimana hewan tersebut berbahasa, serta bagaimana melatihnya untuk mampu menggunakan bahasa.

d) Perbedaan Budaya dalam Bahasa

Bahasa dipengaruhi oleh perkembangan budaya, wilayah, dan perbedaan etnik dalam bahasa. Banyak ahli sosiolinguistik menyatakan budaya dan aspek sosial lainnya mempunyai pengaruh yang besar dalam keragaman bahasa. Dengan kata lain, adanya perbedaan budaya dalam bahasa akan mewarnai ragam bahasa itu sendiri, dan ini perlu disatukan dalam sebuah konsep bahasa.

e) Berbicara dan Otak Manusia

Otak manusia terdiri dari dua hemispheres, yang fungsinya tidak sama. Masing-masing hemispheres tersebut menerima informasi dari indera, tetapi kedua hemispheres tersebut menerima informasi terpisah.

\section{Teori-teori Belajar Bahasa}

Teori belajar bahasa yaitu (Ellis, 1987):

a) Pendekatan Pengkondisian

Pendekatan pengkondisian dalam pembelajaran bahasa membuat asumsi dasar bahwa bahasa dipelajari sesuai dengan prinsip-prinsip dasar pengkondisian. Ini berarti bahwa prinsip-prinsip pengondisian yang diturunkan dari studi organisme tingkat rendah dapat diterapkan pada pemahaman pembelajaran bahasa. B. F. Skinner adalah salah satu psikolog awal yang menganjurkan studi tentang perilaku bahasa dari sudut pandang pengkondisian. Ide dasarnya adalah perilaku verbal seperti kelas perilaku lainnya dan diperoleh melalui penguatan respons verbal yang sesuai. Skinner mengemukakan ada dua jenis penguatan yaitu penguatan positive, penguatan negative dan hukuman (Santrock, 2001). Secara umum, skinner berpendapat bahwa perilaku verbal sama seperti perilaku lainnya yang dipaparkan melalui penguatan respon yang benar. 
b) Pendekatan Psikolinguistik

Kemampuan untuk mempelajari atau memperoleh bahasa melalui pengembangan aturan-aturan yang abstrak merupakan ciri yang unik pada manusia. Pembelajaran bahasa tidak terlepas dari apa yang dikemukakan para linguis tentang bahasa. Orang yang beranggapan bahwa bahasa adalah sebagai fenomena yang bisa dipilah menjadi bagian-bagian secara terpisah, akan memberi perhatian lebih besar kepada cara memahami pembagian masing-masing tersebut. Sementara orang yang beranggapan bahwa bahasa adalah terkait dengan budaya dan merupakan alat interaksi sosial, akan menggunakan metodologi pembelajaran yang kental dengan strategi sosiolinguistik dan komunikatif (Saepudin, 2018).

\section{KESIMPULAN}

Bahasa adalah alat dasar yang digunakan manusia untuk berpikir. Bahasa dibentuk dari berbagai kombinasi kata yang mengacu pada aturan tertentu. Adapun karakteristik bahasa, yaitu: 1) fungsi bahasa, 2) unit dasar bahasa:fonem dan morfem, 3) Level tertinggi dari analisis bahasa, struktur frase dalam kalimat. Adapun isu-isu dalam bahasa yaitu, perkembangan bahasa, bahasa dan proses berpikir, bahsa pada hewan, perbedaan budaya dalam bahasa, berbicara dan otak manusia. Adapun teori-teori belaar bahasa yaitu, pendekatan pengkondisian, dan pendekatan psikolinguistik.

\section{DAFTAR PUSTAKA}

Ellis, H, C. (1978). Fundamentals of Human Learning, Memory, and Cognition.Mexico, Wm. C. Brown Company Publishers Dubuque, lowa.

Harras, K, A. \& Bachari, A, D. (2009). Dasar-dasar Psikolinguistik. Bandung: UPI Press

Hidayat, N. S. (2014). Hubungan Berbahasa, Berpikir, dan Berbudaya. Sosial Budaya: Media Komunikasi Ilmu-Ilmu Sosial dan Budaya, Vol.11, No.2 Juli - Desember 2014.

Indah, R, N. (2008) Proses Pemerolehan Bahasa: Dari kemampuan hingga kekurangmampuan berbahasa. Lingua, 3 (1). ISSN 2442-3823

Indah, R, N. (2017a). Language comprehension. Disampaikan pada mata kuliah Psycholinguistics, Department of English Letters Faculty of Humanities Universitas Islam Negeri Maulana Malik Ibrahim Malang. (http://repository.uinmalang.ac.id/1137/)

Indah, R, N. \& Abdurrahman (2008). Psikolinguistik: konsep \& isu umum UIN Press, Malang. ISBN 979-24-3044-X.

Jumhana, N. (2004). Pemerolehan Bahasa pada Anak (Kajian Teoritis Tentang Pemerolehan Bahasa Pertama), Jurnal al-Ittijah, Pendidikan Bahasa Arab Fakultas Tarbiyah dan Keguruan Sultan Maulana Hasnuddin Banten, Volume 6, Nomor 2.

Muhibbin, S. (2010). Psikologi Pendidikan.PT Remaja Posdakarya Offset: Bandung

Saepudin (2018). Teori Linguistik dan Psikologi dalam Pembelajaran Bahasa. Parepare. IAIN.

Santrock, JW. (2001). Educational psychology,New York: McGraw-Hill. 